\title{
Sparta and the English Republic
}

\author{
Article
}

Accepted Version

Foxley, R. (2016) Sparta and the English Republic. Classical Receptions Journal, 8 (1). pp. 54-70. ISSN 1759-5142 doi: https://doi.org/10.1093/crj/clv015 Available at https://centaur.reading.ac.uk/44454/

It is advisable to refer to the publisher's version if you intend to cite from the work. See Guidance on citing.

Published version at: http://crj.oxfordjournals.org/

To link to this article DOI: http://dx.doi.org/10.1093/crj/clv015

Publisher: Oxford University Press

All outputs in CentAUR are protected by Intellectual Property Rights law, including copyright law. Copyright and IPR is retained by the creators or other copyright holders. Terms and conditions for use of this material are defined in the End User Agreement.

\section{www.reading.ac.uk/centaur}

\section{CentAUR}

Central Archive at the University of Reading

Reading's research outputs online 


\section{Sparta and the English Republic}

Rachel Foxley, Department of History, University of Reading

In 1659-60, as England teetered on the brink of political collapse in the series of events which (as it turned out) was to lead to the restoration of Charles II to the throne, two republican authors were engaged in a bitter dispute about ancient Sparta. Although both authors took pains to establish their scholarly credibility - with differing levels of success - their battle was primarily political, part of a fervent and urgent debate among republicans about how a viable commonwealth might yet be established on the ruins of the interregnum's constitutional experiments and in time to halt a slide towards monarchy. The authors in question were James Harrington, the author of the republican masterpiece of the interregnum, The Commonwealth of Oceana (1656), and Henry Stubbe, a promising young academic and a protégé of the 'godly republican' Sir Henry Vane. The classical Greek focus of their dispute sheds light on the nature of English republican thought, the interplay of classical and scholarly authority with pamphlet debate and political argument, and the malleability of the Greek legacy for early modern readers. The classical offered a route through which political 'innovation', suspect as that always was in early modern England, could be legitimized. But while the rich and sometimes contradictory evidence of ancient texts could be brought to bear in multiple ways, some consensus positions developed in the early modern scholarship posed fairly effective limits to the claims it was possible to make.

Both Harrington and Stubbe were writing in the context of a classical republican tradition (with origins in Italian humanism) which had been overtly and energetically adapted for English audiences by multiple authors only in the wake of the execution of Charles I in 1649 (Pocock 1975: 357-60, 372; Worden 1990: 225-6). The educated were 
schooled in classical texts and arguments about liberty and tyranny, and when the new republic required such arguments, several authors demonstrated their familiarity with Machiavelli and other continental authors, but the extent of any classical republican cast to English political thought before 1649 remains much disputed (Peltonen 1995; Sommerville 2007). Classical texts formed a reservoir of political wisdom drawn on by authors across the political spectrum and sometimes plundered for messages whose piety and triteness could barely align them with any definite political philosophy; conversely, the radical political thought of the 1640s Levellers was not couched in classical terms. The adoption of classical republican discourse in England coincided with political crisis and constitutional experimentation, with the political influence of puritan religiosity, and with the impact of different, de facto and Hobbesian, theories of political authority. The reception of classical constitutional ideas in this period was thus only partly shaped by existing traditions of Italian civic humanism or classical republicanism; a multitude of other circumstances and intellectual influences influenced authors' readings of ancient politics. In Harrington and Stubbe we will see two authors experimenting with the boundaries of classical constitutional vocabulary as they shaped a political tradition for English circumstances.

Republican writers played an ambivalent role in a kingless England from 1649 to 1660, defending republican principles but often critiquing - whether overtly or covertly - the realities of rule first by the purged Rump Parliament and then by Oliver Cromwell as Lord Protector. When Cromwell died in 1658 and his son Richard succeeded him as Lord Protector, criticism burst into the open as republicans saw a chance to rescue the 'good old cause' and establish a true republic. Richard Cromwell was swiftly eased from power and the Rump parliament returned in the spring of 1659 amid a clamour of competing republican and army proposals for a longer-term settlement - among them, 
Harringtonian proposals and examples of 'theocratic republicanism' which were very much at odds with each other (Mayers 2004: 213-228). Classical republican thought since 1649 had taken many forms, with authors drawing on different aspects of a complex tradition: some, such as Milton, emphasized the republican ethic which linked virtue, reason, and liberty, but had little to say about constitutional forms; others, such as Marchamont Nedham, had drawn on Machiavelli's emphasis on the glory and expansion of Rome in its republican period to urge the superiority of a 'free state' over a monarchy. Few, apart from Harrington, offered detailed constitutional prescriptions. It is significant that the dispute over constitutional forms and terms examined in this paper took place in 1659-60, as this was the moment when republicans who had previously been content to commend the embrace of liberty in classical (and godly) republican terms faced up to the need to find institutions which could secure that liberty against imminent political collapse and monarchical restoration. The need to save the commonwealth led to definitional disputes about the constitutions which might qualify as 'commonwealths', and pamphleteers drew inspiration from constitutional features of the ancient republics in their search for mechanisms, whether permanent or temporary, which could safeguard liberty. Harrington and Stubbe's dispute about Sparta was part of a broader dispute about what kind of additional assembly or council might be needed alongside a popular House (in practice the restored Rump parliament of 1659) to secure liberty, and that in turn was framed by Harrington's strictures on the kind of constitution which could really be accounted a commonwealth.

Harrington and Stubbe were both drawn to ancient Sparta as a model for an English commonwealth. Distinguished work by Elizabeth Rawson and Anna Strumia has already examined the treatment of Sparta by Harrington and his antagonists in the 1650s, pinning down the divergent interpretations of Spartan history and institutions 
reached by Harrington and by his royalist opponents Matthew Wren and Peter Heylyn, and his republican sparring partner Stubbe (Rawson 1969: 191-196; Strumia 1991: ixxvii; 48-53; 93-109). Both scholars emphasize the importance of Sparta, certainly as compared with Athens, to Harrington and Stubbe's republican thought, Rawson pointing to Sparta as the equal of Rome in Harrington's work, if inferior to the immortality of Venice (1969: 191-3), and Strumia pointing to Israel and Sparta as appealingly aristocratic models for republicans who disparaged the tumultuous popular politics of Athens (1991: xvi). These comparisons between Athens and Sparta, and between ancient and modern republics, had roots in Italian republican thought. Machiavelli had praised Lycurgus for establishing a mixed constitution, which (according to the Polybian theory) had ensured Sparta's remarkable longevity, compared to the instability of Solon's democracy ('stato popolare') at Athens. However, Sparta, for Machiavelli, was a republic capable of maintaining itself but not expanding, and he preferred Rome, even with its tumults (Machiavelli 2000: 14, 22 - Discorsi 1.2, 1.6); the Spartan model appealed more to Italian admirers of Venice (although it could pale in comparison: Kraye 1997: 131, 137; Rawson 1969: 154-5) who prized La Serenissima's apparent lack of social conflict. On one level, Harrington and Stubbe both fitted the model of 'aristocratic' republicans, far from the populism of the Levellers in the 1640s or of rare populist republicans like Marchamont Nedham or John Streater after 1649 (Foxley 2013b: 194-229). Harrington's political model assumed the existence of a 'natural aristocracy' and gave the rest of the citizenry a carefully circumscribed political role not involving political debate. Stubbe and his patron Sir Henry Vane the younger promoted republican models which would entrust the political direction of the country (at least in the immediate term) only to those who were committed to the godlyrepublican cause. On the face of it, then, it is particularly odd that, while both praising 
Sparta as a model, they both veered away from describing her simply as an 'aristocracy', or as a commonwealth exemplifying the virtues of a mixed polity, and redefined her as a 'democracy' or an 'oligarchy' in polemical ways which led them into dispute with each other. In this article I will argue that a series of Harrington's commitments - to popular sovereignty, however carefully its practice was circumscribed; to a Bodinian description of the form of government according to the single location of sovereignty; to the relationship between landholding and political form; to the possibility of an immortal commonwealth; and to 'ancient prudence' as the basis for politics - led him away from the scholarly consensus that Sparta was an aristocracy towards the idea that she was a democracy. Conversely, Stubbe's positive commitment to restrictive citizenship and a hand-picked senate, designed to secure England against the return of monarchy, meant that he first embraced the consensus that Sparta was an aristocracy, and then (once his position was attacked as oligarchical by Harrington) went further and reclaimed the label 'oligarchy' both for Sparta and for England. This article will flesh out what was at stake in this dispute and the ways in which layers of sources interacted with polemical exigencies to generate both authors' controversial claims.

'Ancient prudence'

Harrington published his elaborate scheme for a reformed commonwealth, The Commonwealth of Oceana, in 1656, at a troubled moment during Oliver Cromwell's protectorate. His professed aim in Oceana was to recover 'ancient prudence', the political wisdom which underpinned the classical republics of Greece and Rome and the biblical republic of Israel. In his view, only Machiavelli among the moderns had 
attempted to recover this, while others had all fallen prey to the amoral principles of 'modern prudence' which justified reason of state and the dominance of monarchies (Harrington 1977: 161-3). This emphasis on the classical past was carried over into the fictional narrative of Oceana, in which the Council of Legislators which was to draw up the orders for the new commonwealth of Oceana 'ransacked' the 'archives of ancient prudence' by allotting particular ancient (but also a few modern) commonwealths to individual councillors to study and report on. First on this list of commonwealths were Israel, Athens, and Lacedaemon (Harrington 1977: 208). Readers have, however, doubted the centrality of classical thought and example to Harrington. Although for J.G.A. Pocock Harrington was a key figure in a genuinely classical republican tradition, and more recently Eric Nelson has emphasized classical Greek thinking as an element of Harrington's thought, other modern scholars have frequently seen Harrington's vaunted allegiance to 'ancient' prudence as masking a thoroughly modern mode of thought, as much influenced by Hobbes and by distinctly modern elements of Machiavellianism as by the ancients (Pocock in Harrington 1977: 15; Pocock 1975: 384-395; Nelson 2004: 87-125; Scott 1993; Rahe 1994: vol 2, 179-96; Rahe 2008: 321346). Certainly, ancient prudence itself was malleable, and Harrington's ancient prudence was very much his own creation: he equated 'ancient prudence' with republican government (1977: 397) and thus read the contemporary Dutch, Swiss and Venetian republics alongside the genuinely ancient material. It was certainly possible to suggest that the ancients did not offer a suitable guide for the present - Stubbe himself did so - but within the classicizing discourse of his dispute with Harrington he had to call on Aristotle's authority even to do this (Stubbe 1659b: 8). But while classical philosophy and the example of the ancients were clearly far from the only or even main determinants of either Harrington or Stubbe's proposals for England, they constituted a 
crucial matrix of material through which these proposals were thought out, tested, and presented.

Harrington's dispute with Stubbe was rather asymmetrical. Stubbe was noted for his brilliance in Greek while an undergraduate, and by the time of their dispute held a Studentship at Christ Church, Oxford and was under-keeper of the Bodleian library, enjoying the patronage of John Owen, the Vice-Chancellor of the University and Dean of Christ Church. Harrington's spell at Trinity College, Oxford, by contrast, did not result in a degree, and although this was not unusual at the time, he showed that it rankled when he suggested that he could 'legitimately' complete the 'exercises' necessary to attain Bachelor's, Master's and Doctor's degrees simply by defeating his opponents with a series of unanswerable arguments in a pamphlet (Jacob 1983: 9-10; 18-19; Harrington 1977: 2, 706). Stubbe found this risible, and in the polemical backand-forth between the authors he accused Harrington of 'trading with Compendiums' rather than returning to the sources in the original $(1660: 6,13)$. Nonetheless, Harrington was working from Latin sources rather than English translations of the classics, and the main compendium which he mined for information on Sparta was an authoritative work also used by Stubbe: the Danish scholar Nicolaus Cragius' De Republica Lacedaemoniorum Libri IIII (1593), treated by early modern readers as the counterpart of the eminent Sigonius' treatise on Athens (Harrington 1656: 56; Emmius 1632: 5-6, and cf. reader's inscription of Emmius passage on British Library copy of Cragius 1593, shelfmark 586.d.20.(1.)).

With Cragius, Harrington and Stubbe were dealing with an author whose work had little overt 'spin'. Cragius (Niels Krag, a diplomat, scholar, and Danish historiographer royal) naturally did not present Sparta as a republican alternative to monarchy. His dedicatory letter to the Danish chancellor painted Sparta as the most 
illustrious of the ancient republics, as evidenced by the virtue of its citizens. Although Cragius emphasized that such virtue was a product of institutions, his letter uncontroversially pointed to education and respect for the laws as routes to this virtue (1593: 2r-4r). Within his text, Cragius avoided drawing overt lessons almost entirely, except for a remarkable outburst lamenting the fact that even learned men and those with political experience now advocated absolute power and license for kings, rather than the strict subordination of the kings to the law seen in Sparta (1593: 57). While strongly worded, this was hardly an avowal of republicanism, although it certainly chimes with Harrington's insistence on the rule of laws rather than men as one of the key principles of 'ancient prudence', and with his contempt for the apparent systematization of self-interested principles in 'modern prudence' (Harrington 1977: 161). More subtly, Cragius displayed a tendency - reflecting broader assumptions in this period - to denigrate 'democracy', translating ' $\delta \eta \mu о \kappa \rho \tau \tau^{\prime} \alpha v$ ' as 'plebis dominatio' rather than simply as 'democratia' or a more usual Latin equivalent such as 'popularis status' (1593: 70). All in all, Cragius appears studiedly moderate, keen to avoid the tyranny of either kings or people, and his scholarly judgements on the question of Sparta's constitutional form were also uncontroversial. What Cragius did, however, was to provide a collection of testimonies from the ancient world, and his own interpretations, which Harrington and Stubbe then read in the light of their polemical needs, their preferred ancient sources (whether in the original or in some kind of translation), and of more modern political thought, such as that of Bodin.

Harrington and Sparta 
Sparta took on a particular significance as a support for several aspects of Harrington's thinking. Fundamental to his theory was the need for a government to be founded on the appropriate balance of landed property. Where the majority of land was in the hands of the people, the government had to be a commonwealth if it was to be stable (and, in Harrington's view, this was now the state of affairs in England). Any government hoping to have a 'long lease' needed an 'agrarian' - a 'law fixing the balance in lands' to make sure that the pattern of land-holding did not once more shift and fatally undermine the political regime based on it (Harrington 1977: 164). Ancient precedents were crucial - and as Harrington's critics were not above remarking, 'examples of an agrarian are so infrequent, that Mr Harrington is constrained to waive all but two commonwealths, and can find in the whole extent of history only Israel and Lacedaemon to fasten upon' (Harrington 1977: 460). Sparta's famed longevity as a republic could thus be explained by its apparent adherence to strict rules enforcing the equal allocation of property among the Spartiates, while the troubles of the Roman republic were inevitable given the failure of the Gracchi (Harrington 1977: 184, 277). As Rawson remarks, Harrington's focus on the landed basis of politics prompted him to offer an unprecedently full, if idiosyncratic, portrait of Sparta, and led to debates with his opponents which were 'the first time since Agis and Cleomenes that the Lycurgan land system has been a matter of even half-practical discussion' (1969: 191,194).

Harrington's theory of the property balance was intrinsically linked to his thinking on constitutional form, and it is this aspect of the struggle over Sparta which I will concentrate on here. The ancient sources furnished a basic repertoire of simple and mixed constitutional forms which had long functioned as a structuring feature of political thinking, and the vocabulary of monarchy, aristocracy, and democracy (and their degenerate forms) had been adopted both in translated forms via Latin and, still 
with a hint of intellectual pretentiousness in some contexts, as Greek loan-words (Harrington 1977: 162; 785). Early modern thinkers, however, challenged the common assumptions which underlay these classifications as discussed in the ancient authors in two ways: absolutists by contesting the possibility or desirability of mixed government, and republicans by challenging the idea that the three undegenerate simple forms of government were equally valid governments, suitable to different circumstances, in favour of a more rigid 'republican exclusivism' which rejected monarchy (Nelson 2007; Wootton 2006: 272-96; Hankins, 2010). Harrington, in typically ambitious and ambiguous style, managed to participate in both these developments while still invoking the classical notions of mixed government and constitutional variation correlated to circumstances.

As I have argued elsewhere, Harrington committed himself to an idiosyncratic version of 'republican exclusivism' in insisting that nothing could be regarded as a commonwealth (or an equal commonwealth) unless it was a popular government or democracy (Foxley 2013a: 180-181, 183). While monarchy would be the legitimate form of government if the corresponding property balance were in place, it would never, according to Harrington, reach the perfection of government that an equal commonwealth would ensure: ultimately, then, democracy was the best form of government. Harrington's insistence on this exclusive democratic definition of republicanism was a crucial shibboleth dividing him from Vane and Stubbe in 1659-60 (Dzelzainis 2014). Sparta was inevitably drawn into Harrington's appropriation of 'democracy', and into his dispute with Stubbe. For a start, Sparta was a key example of stability resulting from the 'balance' of land tallying with the political regime. But there was no doubt in Harrington's mind that the land balance instituted by Lycurgus at Sparta (like Moses' in Israel) was 'democratical or popular' (1977: 459). This could 
hardly be doubted by a reader of Cragius, whose cautious discussion of contradictory evidence in the earlier parts of his discussion of Sparta gave way, in Book 3, to a much more decisive reconstruction of the tables of Spartan 'instituta' in all areas of the polity's life. Their brisk and prominent headings include unequivocal statements of the unalterably equal allocations of land made to Spartiates and the strict regulation of their possessions: 'Sortium numerus idem semper maneat'; 'Possessiones omnium sint aequales'; 'Emere vel vendere possessiones non liceat'; 'Civium numerus sortibus respondeat' ('The number of lots is always to remain the same'; 'the possessions of all are to be equal'; 'The buying and selling of possessions is not to be allowed'; 'the number of citizens is to correspond to the number of lots.' Cragius 1593: 117-9, 123). Sparta's land was thus indisputably in the hands of the whole citizen body. With the balance of land popular and Sparta a key example of a remarkably durable republic, Harrington's theory required him to characterize Sparta as a democracy - which he duly attempted to do, through his mouthpiece the 'Lord Archon' of Oceana:

And now the riddle, which I have heretofore found troublesome to unfold, is out: that is to say why, Athens and Lacedaemon consisting each of the senate and the people, the one should be held a democracy and the other an aristocracy or laudable oligarchy, as it is termed by Socrates (for that word is not, wherever you meet it, to be branded, seeing it is used also by Aristotle, Plutarch and others, sometimes in a good sense). The main difference was that the people in this had the result only, and in that the debate and result too. But for my part, where the people have the election of the senate, not bound unto a distinct order, and the result, which is the sovereign power, I hold them to have that share in the government (the senate being not for life) whereof, with the safety of the commonwealth, 
they are capable in nature, and such a government for that cause to be democracy; though I do not deny but Lacedaemon, the paucity of the senators considered, it might be called oligarchy in comparison of Athens, or, if we look upon their continuance for life, though they had been more, aristocracy. (Harrington 1977: 263; see also 831)

While picking through the exact differences between the ancient republics which rendered some of them more 'equal' and hence more lasting than others, Harrington's fundamental impulse was to assimilate all ancient republics to each other (at least during the periods when they could have been said to be viable republics) and to his specific notion of democracy - a tendency tartly noted by Stubbe when he pointed to Demosthenes' eye-witness testimony that 'the Governments Political of Athens and Sparta were not one and the same' (1660: 12). Ancient prudence did not always cooperate with Harrington's wish that it should speak with a single voice.

Harrington was not alone in wrestling with question of Sparta's constitutional form. Cragius called on the authority of Plato's Laws in support of his view that it was difficult to pronounce correctly on it, and provided a discussion which drew together the terms and reasoning used by different ancient writers, and appropriate to different stages in Sparta's constitutional development, before making his own global assessment of the appropriate term for Sparta's regime (1593: 13-17). However, there clearly was a consensus opinion which made Athens a democracy and Sparta an aristocracy, which Harrington had to wrestle with and which the Lord Archon alluded to. This was Cragius' ultimate conclusion too: among the succession, and sometimes mixture, of forms of regime at Sparta, most authors agreed that aristocracy predominated; the most successful phase of Sparta's history, he judged, was as an aristocracy, and features such as Sparta's use of elections based on virtue rather than sortition reinforced this 
conclusion $(1593: 13,49)$. Harrington clearly had to reckon with this material, and indeed, his lengthy discussion of Sparta's constitution, quoted above, drew on it directly (if silently) in relaying Cragius' assertion and evidence that among the ancients ‘oligarchy' was not always a pejorative term (Cragius 1593: 14).

In The Prerogative of Popular Government, Harrington revisited this question of constitutional terminology, pushing his analysis of the proper classification of the Athenian and Spartan constitutions slightly further. He admitted again that 'Athens is called a democracy' and its constitution 'opposed unto that of Lacedaemon' by the Greeks, who called Sparta an aristocracy or oligarchy. But Harrington insisted that 'according to my principles (if you like them)' slightly different criteria could be used to determine what was 'properly and truly to be called democracy, or popular government.' He now suggested that Athens, strictly speaking, was not a democracy, because 'debate in the people maketh anarchy'; Sparta, where the people (according to his analysis) accepted or rejected legislation but had no power of debate, was a true democracy. But Harrington did not expect his audience to go along with 'my principles', idiosyncratic as they were, without some ancient authority: he argued that 'some of the Athenians themselves' agreed with him, and cited Isocrates' Areopagiticus, where Isocrates, arguing 'for reformation of the Athenian government', described Sparta as a flourishing democracy (Harrington 1977: 479). Thus an ancient critic of Athenian democracy, polemically seeking to push the boundaries of the term away from the usual Athenian understanding of it, became a vehicle for Harrington's own idiosyncratic rehabilitation of the notion of 'democracy'.

Harrington's version of democracy was very particular, and Sparta served his purposes not just because it could be painted as a long-lasting democratic state, but because it offered a more reassuring model, to early modern sensibilities, than the 
alternative of Athens. Harrington's endorsement of democracy is enormously significant (Hammersley 2013; Foxley 2013a) but it does not cancel out the aristocratic elements in his thought noted by many previous scholars. Sparta attracted Harrington not just because it supported his theory of the property balance, but because it offered a model of a commonwealth which was in some senses aristocratic. In Oceana the Lord Archon rhetorically asked 'what comparison is there of such commonwealths as are or come nearest to mechanic; for example, Athens, Switz, Holland, unto Lacedaemon, Rome, and Venice, plumed with their aristocracies?' (Harrington 1977: 259). In Harrington's scheme, there could be no such thing as a pure democracy; it would always be mixed with aristocracy (Harrington 1977: 174, 611). In constitutional terms, this was expressed in his bicameral system, in which the intellectual work of debating and framing legislation was entrusted to an elected senate, while the popular representative assembly would simply judge whether their interests were served by the senate's proposals and vote yes or no accordingly - Harrington enthusiastically endorsed Sparta's reported prohibition on popular debate. This bicameral structure reflected a more fundamental natural division. Harrington argued that there was a 'natural aristocracy' of intellect which would distinguish itself in any society, and in Oceana the process of popular election would help to winnow out this aristocratic element from the 'natural democracy' of the less able (1977: 172-3; 416). In addition, the Senate of Oceana had a property qualification for membership, meaning that however strenuously Harrington objected to separate, hereditary orders of nobility as divisive, he insisted on two rather 'aristocratic' principles on which to divide the citizens of his equal commonwealth. This division, essential to Harrington's thought throughout his brief career as a political writer, did not seem to him to contradict his overall classification of his ideal polity as a democracy. 
We have seen how Harrington juggled with the terminology of constitutions as applied to both Sparta and Athens, but his argument depended not just on adopting the unusual terminology used by some ancient texts (and reported by Cragius), but on interpreting Spartan history. Although authors ancient and early modern were tempted to make overall pronouncements on Sparta's constitution, all conceded that the question was time-bound, and had to identify particular periods in Sparta's history as salient. Stubbe indeed pointed out that some of the sparse evidence for Sparta as a 'democracy' dated from after the Peloponnesian War, and thus could not logically be used in support of Harrington's argument, which dated the debasement of the original Spartan regime from that point (1659b: 5). Harrington's argument, however, rested on the notion that a commonwealth with the right balance and the right orders could be immortal; Sparta and Venice were models because they seemed to have approached this ideal according to mythologising accounts of their longevity. Harrington did not believe that chance or the incremental workings of a non-ideal political system were likely to produce the carefully engineered commonwealth which could achieve such longevity: rather, it would be the product of a far-sighted founder who could put the whole system in place at once. Lycurgus exemplified this ideal: the short concluding section of Oceana borrowed from Plutarch's Lycurgus the story of how Lycurgus immortalised his orders at Sparta by sacrificing his life so that the Spartans were eternally bound to their promise not to change the laws until he returned to them (Harrington 1977: 341). In Harrington's text, as in Plutarch's, the acknowledgement of change after Lycurgus' time was present within the text but elided in a triumphal conclusion.

Harrington thus had to argue for a fundamental stability of the constitution from Lycurgus' time, and this constitution needed to approach as closely as possible to democracy. Harrington achieved this by reading carefully selected parts of the ancient 
evidence in Cragius through a distinctively modern argument: Bodin's theory of indivisible sovereignty. Polybius had seen Sparta as the exemplar of a mixed polity, but although Harrington paid lip service to the notion of the mixed constitution (1977: 162) he wanted to call his ideal constitution, even if it had elements of mixture, a democracy. In this, he followed Bodin, who had elaborated a theory of indivisible sovereignty according to which even apparently mixed states could be classified simply according to where sovereignty lay. An apparent mixture of monarchy, aristocracy, and democracy would in fact be a democracy, since in it all the people would share in the sovereignty (Bodin 1586: 176). Bodin's theory became associated with monarchist and absolutist positions, but Harrington attacked Hobbes and his deployment of Bodin while himself using the Bodinian criterion of popular sovereignty to characterize both Oceana and Sparta as democratic.

The core of the Spartan constitution, in Harrington's reading, was the balanced, bicameral combination of a popular assembly with a senate (the gerousia). Lycurgus was the accepted author of these elements of the constitution, but Cragius reported a consensus that Lycurgus had set up an aristocracy. Bodin, more helpfully, saw the original Lycurgan constitution as a democracy ('popularem statum'); Lycurgus had given 'imperium' and 'maiestas' to the people themselves, as they were able to confirm or reject the senate's proposals. Only later had the state become aristocratic (Bodin 1586: 177-8). Other sources (Isocrates and Aristotle) which made Sparta a democracy referred to the period after the institution of the ephors rather than to the original Lycurgan dispensation (Cragius 1593: 14-15). Harrington's task was to combine these two views: Lycurgus set up a democracy (in which the popular assembly had the final determination of legislation and the people elected the senate and the magistrates), and it was continued once the ephors were in place. In his interpretation, there was only the 
briefest interlude between the senate's attempt to override popular decisions on legislation (as mandated by the Great Rhetra recorded in Plutarch's Lycurgus) and the restoration of popular sovereignty under the ephors - both events taking place, as Plutarch suggested, in the reign of Theopompus, about 130 years after the time of Lycurgus (Plutarch 2005: 9-10).

Harrington had to make one very awkward move in order to paint Sparta as a democracy, but it seems to have been one he was relatively comfortable with. As with other early modern authors, he may routinely have assumed that citizenship had boundaries, beyond which the remainder of the population - in the case of Harrington's Oceana, this was made up of 'servants' who by definition lacked the means to 'live of themselves' - were barely considered as constituting part of the polity when its political arrangements were considered. As he briskly remarked, the exclusion of servants from citizenship 'needeth no proof' as 'servitude... is inconsistent with freedom or participation of government in a commonwealth' (Harrington 1977: 212). Sparta, like Venice, presented the problem of a commonwealth whose tiny citizen body was out of all proportion to its actual population. Harrington acknowledged that in a 'commonwealth for increase' this would be problematic, but in these two small commonwealths which were only attempting to maintain themselves rather than grow, the small citizen body had the great advantage that it could - by an odd and very Harringtonian sleight of hand - both be exemplarily equal and democratic, and be noble and aristocratic. To have a citizen body divided into hereditary orders would be fatal to the 'equality' of a commonwealth, causing dissension, but Harrington relished the paradoxical notion of a commonwealth in which the entire citizenry was noble (Harrington 1977: 260-1, 426-7, 438). 
The dispute with Stubbe

In the republican debates of 1659 , Harrington's writings offered by far the most developed, ready-made constitutional proposals which were available: many of the republicans of the 1650s had paid scant attention to constitutional prescription, or had addressed it only in the most general terms. But the urgent need in 1659 to find a stable non-monarchical settlement which could resist attempts at restoration or king-making made some fear that Harrington's ideal was impracticable or even positively dangerous. Conversely, Harrington feared the implications of rival republican proposals which were either unicameral (with a council ruling in the intervals between sittings) or demanded, as the army had in May, a 'select Senate' or even 'ephors' set over the popular house (The Humble Petition, 1659: 10-11; Ludlow 1894: II, 99; Nippel 1994: 22-24). Harrington's response to such proposals, in his pamphlets of May 1659, was to focus on the danger of an 'oligarchy' snatching away the possibility of any commonwealth, as well as on the imperfections which might render a commonwealth not 'equal' (Harrington 1977: 730, 736-7, 739, 745). Although he distinguished between oligarchy - as something which could prevent a commonwealth being settled at all and a senate for life or optimacy, which would prevent it being an 'equal' commonwealth, Harrington pointed out that an oligarchy 'may consist of a council not elected by the people, but obtruded upon us under the notion of a senate' (Harrington 1977: 730). An elected senate, even if for life (as at Sparta), was at least consistent with a commonwealth; but the army proposal, backed by Stubbe, was for a select, not elected senate.

In the preface to his Essay in Defence of the Good Old Cause in September 1659, Stubbe defended his version of the republican cause on two fronts: against Richard 
Baxter's Holy Commonwealth and against the Harringtonian accusation of oligarchy. Professing his admiration of Harrington, he nonetheless argued that there was nothing wrong with an 'unequal' commonwealth, and that the coordinate senate he supported, rather than becoming an 'oligarchy', could be an essential foundational period of rule comparable to that of Lycurgus or Moses - the lawgivers most admired by Harrington. That some of Stubbe's professed admiration for Harrington was real is suggested by the fact that while he disputed his interpretation of 'oligarchy', he actively utilised a positive, Harringtonian, interpretation of 'democracy' in arguing against the conventionally anti-democratic Baxter (Stubbe, 1659a: Preface, unpaginated). Stubbe was thus already thoroughly engaged in a public conversation with Harrington about the meaning and applicability of the classical constitutional terminology, but it was a month later, in October, that he joined battle with Harrington directly over the interpretation of Sparta, and began both to hint at the possible reclamation not just of the select coordinate senate from the accusation of oligarchy, but also at the reclamation of 'oligarchy' itself from its pejorative overtones. In his Letter to an Officer of the Army concerning a Select Senate, Stubbe again defended the proposal for a select senate against charges of oligarchy, but felt compelled to add a marginal note:

I take Oligarchy here, as the ignorant Vulgar mistake it; for the corruption of Aristocracy; whereas Oligarchy is but the Government of a few, and not of the Body: And it is observed by Crag. upon the Spartan Republick, that Oligarchy is a word of an Innocent, yea, a good signification; and the Reiglement of Lacedaemon is called an Oligarchy by Isocrates, and others; though he who shall examine the institution of the Senate will say it was made up of the best, and so was an Aristocracy. (Stubbe 1659b: 2-3) 
As well as following Cragius' comment (also relayed by Harrington), Stubbe here insisted on a value-neutral etymological reading of the meaning of oligarchy, and from the Isocratean verdicts reported by Cragius, Stubbe chose to highlight his reference to Sparta as an oligarchy where Harrington had used his description of it as a democracy. However in the main text of his work, Stubbe developed the argument not that Sparta was an oligarchy but that it was an 'Aristocracy' or an 'Optimacy'. He framed his argument in unmistakeably Harringtonian terms, precisely in order to overturn the implications of Harrington's arguments. He agreed with Harrington that Lycurgus had initially established 'an equal Common-wealth... in a Senate proposing, and people resolving'; what is more, he did so in far more advantageous conditions than applied in England in 1659. However, this state (which Stubbe does not specifically describe as democratic or popular, but which the Harringtonian language would imply was so) did not last, as the Spartans after only '100, or 130 years' decided that 'they preferred an Aristocracy' (Stubbe 1659b: 4-5). He contrasted this with 'the popular constitution of Athens' and emphasized the ideological aspect of the struggle between Athens and Sparta in the Peloponnesian War (Stubbe 1659b: 5). But he did not paint Sparta as an oligarchy or defend oligarchy as such.

Stubbe took that step only after his Letter to an Officer of the Army had met with a slight and dismissive response from Harrington, insultingly entitled 'A Sufficient Answer to Mr Stubbe', appended to Harrington's Valerius and Publicola of OctoberNovember 1659. Largely ignoring the more detailed discussion within Stubbe's pamphlet, Harrington objected to the way in which Stubbe had flipped round Harringtonian ideas to reach opposite conclusions, and characterized the result as 'the lively emblem of an oligarchy' (Harrington 1977: 804-5). Stubbe's positive insistence that an 'unequal' commonwealth might be the preferable option for England, and 
perhaps his advocacy of a fairly detailed scheme of elections and powers which had a Harringtonian feel but ignored Harringtonian principles, might understandably have riled him (Stubbe 1659b: 57, 62-3). At any rate, his dismissive response, perhaps combined with changed political circumstances, liberated Stubbe to move one stage further in his argument in his final challenge to Harrington, The Common-Wealth of Oceana Put into the Ballance, and found too light. Or An Account of the Republick of Sparta, probably published after the return of the excluded members to the Rump parliament had made restoration inevitable. Here Stubbe offered an account of the development of Sparta's constitution, ostentatiously laced with passages from the sources in the original Greek, and including corrections on minor points of scholarly disagreement, which in essentials repeated what he had argued the previous autumn: the 'Oceanistical Platform' on which Lycurgus founded Sparta lasted no longer than 130 years, and was replaced by a constitution in which the senate could overrule the people. It was this undemocratic model which Sparta then exported to her allies. The difference, in Stubbe's final account, is that he now insisted that the Spartans called their regime 'an Oligarchy, and Aristocracy, (but the former name, I think, is more usual)'. Stubbe consistently described Sparta as an oligarchy here, cherrypicking the sources to enable him to do so (1660: 11). Not satisfied with this, Stubbe went further, suggesting in his preface that until the time of Pericles, the powers of the Areopagus made even Athens 'almost an Aristocracy (as Sigonius confesseth)' (1660: 'To the Reader', unpaginated). Although he accepted that Athens then became a democracy, he used this conclusion to argue that 'by how much the Spartans are of more repute than the Athenians, and their republick more celebrated, so far Oligarchy is advanced above Democracy' (Stubbe 1660: 14). 
Stubbe's logic in defining constitutions was mixed: while he drew on etymology and on ancient descriptions of the constitutions of Athens and Sparta, further arguments were apparent. He suggested that Harrington was failing to follow the principles of ancient nomenclature in saying 'that where the over-ballance of land \& power was in a few, it was Aristocracy, though Aristotle do constantly avow it to be Oligarchy' (Stubbe 1660: 'To the Reader', unpaginated). In Harrington's Valerius and Publicola the government of a few was said not to be an aristocracy 'where there is not a nobility sufficiently balanced or enriched', but only an oligarchy (Harrington 1977: 785). While in theory Harrington had clung on to the ancient ethical requirements of good government, his account of the distinction between the original and the degenerate simple forms of government hinged on the fit between the property balance and the political regime as well as on the directly ethical criteria suggested by ancient authors: in the degenerate forms of government, power did not rest on the property balance, and hence could not be maintained without violence (Harrington 1977: 164; Foxley 2013: 187-8). Thus, as Nelson points out, Harrington at one point mistranslates Aristotle, conflating virtue with eminence in property-holding - which, as Stubbe noted, were very much distinct in Aristotle's thinking (Nelson 2004: 111). In effect, Stubbe hinted, Harrington was abandoning the ancient principles of ethical politics which he claimed to espouse.

In general, however, Stubbe defined polities in exactly the same way as Harrington: through Bodin's criterion of sovereignty. In the case of Sparta, this required an examination of who had the final power of legislation after the reign of Theopompus and Polydorus - since Stubbe and Harrington were prepared to agree that the Lycurgan system put in place about 130 years earlier was popular. Cragius offered grist for both their mills, in separate accounts of the power of the people, the senate, and the ephors 
which tended to generalise about the Spartan constitution rather than pin it down to a particular phase of its history, but which also pulled in different directions on the question of sovereignty. In Plutarch's account, the institution of the ephors fell in Theopompus' reign, along with the newly acquired ability of the senate to overrule the people's legislative decisions. For Harrington, the ephors were a rapid and effective popular response to this infringement of the people's legislative sovereignty. Cragius helpfully claimed that the people's power in their assemblies was restored under the ephors (1593: 32); as Stubbe pointed out, warrant for this belief was hard to find in the ancient sources, which framed the powers of the ephors in rather different terms, and not in terms of involvement in legislative decisions (Stubbe 1659b: 5; Stubbe 1660: 13). Nonetheless, Harrington followed Cragius, and elaborated on the powers over the kings and senators which the ancient sources did give to the ephors, arguing that these powers were used if kings and senators went about 'to subvert the fundamental laws of their government, by which it belonged unto the senate to debate and propose only, and to the people to resolve' (Harrington 1977: 731). Thus popular sovereignty, through the people's electoral and legislative power, was secure.

For Stubbe, by contrast, the criterion of sovereignty gave a clear verdict in favour of oligarchy, not democracy, at Sparta, and he emphasized that he was applying this criterion even more single-mindedly than Harrington, who muddied the waters by discussing the presence or absence of 'equality' within a (democratic) commonwealth on criteria such as rotation of office:

The power of the Athenian people is opposed to that of the Spartan Senate; and not the defect of rotation in one Senate above the other; nor the power of debating in the Democracy of Athens, which wanted in Sparta: but the final result is fixed in the Spartan Senate. 
In short, the only significant difference was 'that in Athens the PEOPLE had the SOVERAIGNTY, \& in Sparta the SENATE. It is therefore apparent that Lacedaemon was no Oceanistical Republique, but an Oligarchy' (Stubbe 1660: 12-13). Cragius' chapter on the senate gave ample grounds for such a view, emphasizing the supreme power of the senate and citing, as Stubbe did, Demosthenes' argument that a Spartan elected senator immediately became 'MASTER over the people' (Cragius 1593: 70-71; Stubbe 1660: 12). Cragius qualified this claim by suggesting that the senate's original power was curbed by the institution of the ephors, but did not explain how Demosthenes' evidence for the fourth century tallied with this. A reader could easily draw Stubbe's conclusions from the overall emphasis of this chapter, just as they could draw Harrington's conclusions from the emphasis of the chapter on the popular assembly. But Cragius' discussion of the institution of the senate not only supported his overall description of Sparta as an aristocracy, but went out of its way to endow the senate with a role not just in restraining the power of the kings (as Plato's Laws argued) but in checking the danger of 'plebis dominatio': for Cragius, Plato's one-sided version needed to be interpreted by Plutarch's deliberately balanced account, which he quoted at length (Cragius 1593: 69-70). For Cragius, the Spartan senate specifically averted the threat of popular rule. Stubbe's further interpretation of the evidence, in favour of oligarchy rather than aristocracy, was a presumably a back-handed tribute to Harrington's own vocabulary: he was not only prepared to defend what Harrington condemned as oligarchy, but to defend it under that name.

Along with the location of sovereignty, the other crucial factor in classifying Sparta's constitution was the question of the inclusion and exclusion of its residents from the bounds of citizenship. Harrington, as we have seen, airily dismissed the significance of the non-free population of Sparta, allowing him to claim Sparta as a 
near-democracy and an example of equality - perhaps the aristocratic 'equality' of the 'homoioi'. This position was not without its strains for Harrington, especially when it came to the debates of 1659-60. Against Stubbe's proposals not only to institute a select senate, but also to distinguish the loyal 'people', as citizens, from the broader 'nation', Harrington retorted 'that he [Stubbe] would have all the rest of the people of England to be helots' (1977: 804). Stubbe had himself invited this comparison, explicitly tackling the question of how the 'people' (the citizen body) should be defined and arguing - in ways that were certainly directed against Harrington as well as against aspects of received opinion (Jacob 1983: 29) - that owning or working land in a particular place was neither 'necessary' nor 'sufficient' for citizenship there. Both these points he attempted to prove by reference to Sparta, in the first case without elaboration, but in the second with two specific arguments. Those who held or worked land in Laconia might not be Spartan citizens for two different reasons. Firstly, 'The Helots were not the people of Lacedemon, though they were the Boores and pesantry thereof, renting the whole Countrey, and infinitely more in number than the Lacedemonians'. Secondly, according to Xenophon, Spartan citizens who failed to comply with the 'fundamental discipline' required of them could be deprived of their citizen status without losing their allocations of land (Stubbe 1659b: 52). Harrington and Stubbe both pointed to the helots' non-citizen status within the Spartan commonwealth, but for opposing reasons. Harrington wanted to show that Sparta was a model for a democratic commonwealth in England (by showing that 'internally' it was 'equal'); Stubbe that it was a model for an exclusive commonwealth (in that the majority of its residents were not citizens). For Stubbe, however, emphasizing the numbers and offering a notably positive gloss on the status of the helots (as a kind of tenant farmers rather than slaves) allowed him to paint a picture of a society that constituted a broader 'nation' in England, but which would be 
ruled (at least temporarily) by a much smaller group of full citizens. For Harrington, minimizing the importance of the helots by putting them outside the boundary of the Spartan polity itself - so that they were merely an 'external' problem - meant that Stubbe's comparison of the bulk of the English people to the helots was a cause for outrage.

Conclusion

Both the ancient authors and early modern scholarship offered a matrix of criteria for constitutional definitions, and a spectrum of possible classifications for Sparta, with 'aristocracy' or some form of mixed government the consensus position. It was not possible to ignore these materials, but both Harrington and Stubbe exploited the inconsistencies and instabilities of ancient texts and early modern interpretations of them to make arguments which pushed against the boundaries of both ancient and early modern consensus: Harrington in making Sparta a democracy; Stubbe in positively advocating oligarchy. Both also sought to question Athens's reputation as simply a democracy. Harrington's arguments demonstrate that early modern readers did not necessarily take Athens as the central or best exemplar even of 'democracy', while Stubbe's ripostes suggest that even where Sparta was seen as exemplifying 'oligarchy' this did not rule it out as a valid model. Although the constitutional labels attached to the preeminent ancient polities were broadly agreed, at this tipping-point in the English Revolution the imperatives of contemporary politics prevailed over the scholarly consensus. 
References

Anonymous. 1659. The Humble Petition and Adresse of the Officers of the Army (London: Henry Hills and Francis Tyton)

Bodin, Jean. 1586. Io. Bodini Andegavensis, De Repvblica Libri Sex (Leiden)

Cragius, Nicolaus. 1593. Nic. Cragii Ripensis De Republica Lacedaemoniorum Libri IIII (Geneva: apud Petrum Santandreanum)

Dzelzainis, Martin. 2014. 'Harrington and the Oligarchs: Milton, Vane and Stubbe', in Dirk Wiemann and Gaby Mahlberg (eds), Perspectives on English Revolutionary Republicanism (Farnham: Ashgate), pp. 15-33

Emmius, Ubbo. 1632. Graecorvm Respvblicae ab Vbbone Emmio Descriptae (Leiden: Elsevier)

Foxley, Rachel. 2013a. 'Democracy in 1659: Harrington and the Good Old Cause', in Stephen Taylor and Grant Tapsell (eds), The Nature of the English Revolution Revisited: Essays in Honour of John Morrill (Woodbridge: Boydell \& Brewer), pp. 175-96.

------- 2013b. The Levellers: Radical Political Thought in the English Revolution (Manchester: Manchester University Press).

Hammersley, Rachel. 2013. 'Rethinking the Political Thought of James Harrington: Royalism, Republicanism and Democracy', History of European Ideas, 39: 35470.

Hankins, James. 2010. 'Exclusivist Republicanism and the Non-Monarchical Republic', Political Theory, 38: 452-82.

Harrington, James. 1656. The Common-Wealth of Oceana (London: Livewell Chapman) 
1977. The Political Works of James Harrington, ed. by J.G.A. Pocock

(Cambridge: Cambridge University Press)

Jacob, James R. 1983. Henry Stubbe, Radical Protestantism and the Early

Enlightenment (Cambridge: Cambridge University Press)

Kraye, Jill. 1997. Cambridge Translations of Renaissance Philosophical Texts: vol 2: Political Philosophy (Cambridge: Cambridge University Press)

Ludlow, Edmund. 1894. The Memoirs of Edmund Ludlow: Lieutenant-General of the Horse in the Army of the Commonwealth of England 1625-1672 (Oxford:

Clarendon Press), 2 v

Machiavelli, Niccolò. 2000. Discorsi sopra la prima deca di Tito Livio, ed. by Corrado Vivanti (Turin: Einaudi)

Mayers, Ruth E. 2004. 1659: The Crisis of the Commonwealth (Woodbridge: Boydell Press).

Nelson, Eric. 2004. The Greek Tradition in Republican Thought (Cambridge: Cambridge University Press)

-------- 2007. “ “Talmudical Commonwealthsmen” And the Rise of Republican Exclusivism', Historical Journal, 50: 809-835

Nippel, Wilfried. 1994. 'Ancient and Modern Republicanism: "Mixed Constitution" And "Ephors"', in The Invention of the Modern Republic, ed. by Biancamaria Fontana (Cambridge Cambridge University Press), pp. 6-26

Plutarch. 2005. Lycurgus; translated in R.J.A. Talbert, Plutarch on Sparta (Harmondsworth: Penguin, revised edn)

Peltonen, Markku. 1995. Classical Humanism and Republicanism in English Political Thought, 1570-1640 (Cambridge: Cambridge University Press) 
Pocock, J. G. A. 1975. The Machiavellian Moment : Florentine Political Thought and the Atlantic Republican Tradition (Princeton ; London: Princeton University Press)

Rahe, Paul A. 1994. Republics Ancient \& Modern. Vol 2: New Modes and Orders in Early Modern Political Thought. 3 vols. Vol. 2 (Carolina: University of North Carolina Press)

2008. Against Throne and Altar : Machiavelli and Political Theory under the English Republic (Cambridge: Cambridge University Press), pp. xii, 422 p.

Rawson, Elizabeth. 1969. The Spartan Tradition in European Thought (Oxford: Clarendon Press)

Scott, Jonathan. 1993. 'The Rapture of Motion: James Harrington's Republicanism', in Nicholas Phillipson and Quentin Skinner (eds), Political Discourse in Early Modern Britain, ed. by (Cambridge: Cambridge University Press), pp. 139-63.

Sommerville, Johann. 2007. 'English and Roman Liberty in the Monarchical Republic of Early Stuart England', in John F. McDiarmid (ed.), The Monarchical Republic of Early Modern England (Aldershot: Ashgate), pp. 201-16.

Strumia, Anna. 1991. L'immaginazione Repubblicana: Sparta e Israele nel Dibattito Filosofico-Politico dell' Età di Cromwell (Florence: Casa Editrice Le Lettere)

Stubbe, Henry. 1659a. An Essay In Defence of the Good Old Cause (London).

--------1659b. Henry Stubbe, A Letter To An Officer of the Army Concerning A Select Senate (London: printed by T.B., 1659)

--------1660. The Common-Wealth Of Oceana Put into the Ballance, and found too light. Or An Account of the Republick of Sparta. London: Giles Calvert)

Wootton, David. 2006. 'The True Origins of Republicanism: The Disciples of Baron and the Counter-Example of Venturi', in Manuela Albertone (ed.), Il 
Repubblicanesimo Moderno: L'idea di Repubblica nella Riflessione Storica di Franco Venturi (Naples: Bibliopolis), pp. 271-304

Worden, Blair. 1990. 'Milton's Republicanism and the Tyranny of Heaven', in Gisela Bock, Quentin Skinner and Maurizio Viroli (eds), Machiavelli and Republicanism (Cambridge: Cambridge University Press), pp. 225-45 